\title{
Jurist-Diction
}

Volume 2 No. 5, September 2019

Histori artikel: Submit 28 Juli 2019; Diterima 23 Agustus 2019; Diterbitkan online 1 September 2019.

\section{Implementasi dan Urgensi Pengaturan Zona Tambahan di Wilayah Perairan Indonesia Berdasarkan United Nations Convention On The Law Of The Sea 1982}

\author{
Giustin Aryahya Lubis \\ giuslubis@gmail.com \\ Universitas Airlangga
}

\begin{abstract}
Problems with violations of law that often occur both in the customs and immigration fields in Indonesian jurisdictions, especially entering through the sea, make the need for monitoring and prevention efforts so that various forms of lawlessness in these fields can be minimized. UNCLOS 1982 as an international legal arrangement that regulates matters concerning marine issues has actually been accommodated, namely by regulating a sea zoning that can be used for UNCLOS 1982 participating countries to supervise and prevent violations in four fields in accordance with Article 33 UNCLOS 1982. However, ratification of UNCLOS 1982 that Indonesia has done is still considered as not achieving legal certainty, considering the fact that legislation has not been established specifically to regulate the existence of Contiguous Zones in Indonesia.
\end{abstract}

Keywords: Violations of law; Contiguous Zones.

\begin{abstract}
Abstrak
Permasalahan pelanggaran hukum yang kerap kali terjadi baik dibidang kepabeanan maupun keimigrasian di dalam yurisdiksi Indonesia khususnya masuk melalui jalur laut, menjadikan perlunya upaya pengawasan dan pencegahan agar berbagai bentuk pelanggaran hukum di bidang-bidang tersebut dapat ditekan seminimal mungkin. UNCLOS 1982 sebagai pengaturan hukum internasional yang mengatur perihal permasalahan kelautan sejatinya telah mengakomodasi yaitu dengan diaturnya suatu zonasi laut yang dapat digunakan bagi negara peserta UNCLOS 1982 untuk melakukan pengawasan dan pencegahan terhadap pelanggaran dalam empat bidang sesuai dengan Pasal 33 UNCLOS 1982. Namun tindakan ratifikasi terhadap UNCLOS 1982 yang telah dilakukan Indonesia masih dianggap belum mencapai memenuhi kepastian hukum memperhatikan belum dibentuknya peraturan perundangundangan yang khusus dalam mengatur adanya Zona Tambahan di Indonesia.
\end{abstract}

Kata Kunci: Pelanggaran hokum; Zona Tambahan.

\section{Pendahuluan}

Indonesia merupakan negara dengan total luas wilayah sebesar 7,81 juta $\mathrm{km}^{2}$ yang terbagi dari 2,01 $\mathrm{Km}^{2}$ daratan dan 5,8 juta $\mathrm{km}^{2}$ luas lautan beserta Zona Ekonomi Eksklusif. ${ }^{1}$ Dengan luas perairannya yang hampir dua kali lebih besar dari pada luas daratannya, Indonesia menyediakan berbagai sumber daya alam yang berlimpah dan dapat ditemukan dalam lautan Indonesia sehingga berguna

1 Kementrian Kelautan dan Perikanan Republik Indonesia, (2018) $<\underline{\text { https://kkp.go.id/artike- }}$ 1/2233-maritim-indonesia-kemewahan-yang-luar-biasa $>$, diakses pada 6 September 2018. 
bagi kemaslahatan masyarakatnya. Wilayah laut yang luas menjadikan Indonesia dikenal sebagai negara maritim, pengaturan mengenai laut menjadi hal yang harus diprioritaskan bagi negara ini.

Di tahun $1967,{ }^{2}$ Indonesia bersama dengan kurang lebih 150 negara anggota Perserikatan Bangsa-bangsa lainnya terlibat dalam percaturan internasional bersejarah mengenai perkembangan pengaturan hukum laut internasional. Perkembangan tersebut tercipta dengan munculnya panitia persiapan untuk Konferensi Hukum Laut III yang menghasilkan United Nations Convention on the Law of the Sea 1982 yang selanjutnya disebut UNCLOS 1982. Salah satu hukum Internasional yang mengatur mengenai hukum laut ini juga memuat pembagian batasan zona maritim yang salah satunya disebut sebagai zona tambahan. Pasal 33 ayat (1) UNCLOS 1982 menjelaskan menjelaskan lebih lanjut terkait tujuan adanya zona tambahan, yaitu sebagai bentuk pengawasan dan pencegahan adanya pelanggaran peraturan perundang-undangan berkaitan dengan bea cukai, fiskal, imigrasi ataupun saniter.

Permasalahan terkait hal-hal yang sepatutnya diberlakukan dalam zona tambahan apabila tidak diatur secara khusus dalam peraturan perundang-undangan nasional sejatinya dapat menjadi cikal bakal adanya gangguan terhadap kedaulatan pada negara yang tidak menerapkan zona tambahan tersebut. Pada tahun 1980$\mathrm{an}^{3}$ ada suatu kejadian dimana pihak asing, yaitu warganegara Belanda melakukan kegiatan pengangkatan kerangka kapal Geldermarsen beserta muatannya yang kemudian dibawa ke Negara Belanda dari zona maritim yang seharusnya menjadi zona tambahan Indonesia. Pemerintah Indonesia saat itu tidak melakukan tindakan apapun karena tidak memiliki dasar hukum penindakan terhadap Belanda mengingat pemerintah Indonesia belum mengumumkan batas terluar Zona Tambahan Indonesia, memperhatikan pula tindakan Belanda tersebut dianggap sebagai suatu pelanggaran

\footnotetext{
2 A.K., Syahmin, Beberapa Perkembangan dan Masalah Hukum Laut Internasional (Sekitar Penegakan Hukum di Perairan Yurisdiksi Nasional Indonesia Dewasa ini), (Binacipta 1988).[3].

3 BPHN Departemen Hukum dan HAM RI disusun oleh Tim Kerja di Bawah Pimpinan Prof. Dr. Etty R. Agoes, S.H., LL.M.,(2008), Laporan Tim Naskah Akademik tentang Zona Tambahan Indonesia: Analisis dan Evaluasi Hukum tentang Zona Tambahan.[3].
} 
karena dilaksanakan tanpa persetujuan Indonesia sesuai Pasal 303 ayat (2) UNCLOS 1982. Dalam hal ini Indonesia sebagai negara pantai sudah jelas dirugikan dikarenakan masih berkewajiban untuk melindungi benda-benda bersejarah namun dikarenakan pengaturan zona tambahan belum diatur secara jelas membuktikan lemahnya aturan tersebut dalam peraturan perundang-undangan di Indonesia.

\section{Metode Penelitian}

Metode penelitian yang digunakan dalam penelitian adalah doctrinal research atau normatif yang bertujuan untuk menemukan kebenaran berdasarkan kesesuaian aturan hukum dengan norma hukum, dan norma hukum dengan asas hukum. ${ }^{4}$ Dalam penelitian ini akan dibahas mengenai prinsip-prinsip hukum internasional, pendapat para ahli hukum internasional, serta peraturan-peraturan terkait hukum laut, khususnya pada zona tambahan.

\section{Konsep dan Urgensi Zona Tambahan menurut United Nations Convention On The Law Of The Sea 1982}

Diawali dari pembentukan UNCLOS 1982 yang bermula pada tahun 1930, dimana negara yang tergabung dalam liga bangsa-bangsa merasakan perlunya membuat suatu produk hukum internasional yang mengatur mengenai permasalahan perairan territorial, yang menjadikan hal tersebut sebagai salah satu prakarsa untuk dapat diadakan konferensi kodifikasi hukum internasional berdasarkan resolusi sidang ke-V Majelis Liga Bangsa-Bangsa yang berlangsung di Den Haag. Namun hingga Konferensi Den Haag ini berakhir pun masih belum menciptakan aturan hukum internasional baru sehingga diperlukanlah pertemuan/konferensi selanjutnya untuk menghasilkan bentuk pengaturan hukum laut internasional khusus.

Negara-negara peserta Perserikatan Bangsa-Bangsa yang berjumlah 86 Negara turut serta dalam konferensi hukum laut Jenewa tahun 1958 yang didasarkan pada resolusi Majelis Umum PBB No. 1105 (XI) tanggal 21 Februari 1957. Konferensi

\footnotetext{
4 Peter Mahmud Marzuki, Penelitian Hukum (Prenada media Group 2016).[47].
} 
yang berlangsung dari tanggal 24 Februari hingga 27 April 1958 terbagi atas empat komite dan masing-masing komite memiliki tugasnya masing-masing, seperti komite satu yang bertugas untuk menangani soal-soal yang bertalian dengan laut territorial dan jalur tambahan, dalam komite ini perundingan terkait lebar laut territorial masih belum dapat menemukan titik temu sehingga konferensi ini masih gagal menentukan lebar laut territorial dan jalur tambahan dan Majelis Umum PBB di tahun tersebur memutuskan untuk mengadakan konferensi kedua berkaitan dengan penetapan masalah lebar laut territorial dan jalur tambahan (zona tambahan). Dari Konferensi Hukum Laut kedua ini berakhir dengan hasil empat buah konvensi mengenai hukum laut publik, sebuah protocol fakultatip mengenai penyelesaian pertikaian dan 9 buah resolusi. ${ }^{5}$ Empat buah konvensi yang dimaksud yaitu:

1. Geneva Convention on The Territorial Sea and Contiguous Zone 1958;

2. Geneva Convention on The High Seas 1958;

3. Geneva Convention on Fishing and Conservation of the Living Resources of the High Seas 1958;

4. Geneva Convention on Continental Shelf 1958.

Majelis Umum PBB dengan resolusi No. 3067 tanggal 16 Nopember 1973 menetapkan bahwa adanya Konferensi hukum laut lanjutan sebagaimana disebut Konferensi Hukum Laut PBB III akan diadakan tahun 1973 dengan susunan organisasi yang terdiri dari:

1. Komite Kredensial;

2. Komite Pengarah;

3. Komite Perancang;

4. Tiga Komite Utama guna menangani isu-isu pokok.

Konferensi ini pun terlaksana melalui beberapa sidang yang bergiliran di masing-masing negara peserta, dimana terdapat 12 putaran sidang dan pada putaran sidang terakhir yaitu sidang ke-duabelas ditahun 1982 bertempat di Montego Bay lahirlah konvensi PBB tentang hukum laut yang baru yakni UNCLOS 1982, Sebagai konvensi hukum laut yang baru menjadikan pembaharuan hukum laut internasional menggantikan berbagai konvensi hukum laut yang yang tercipta pada konvensi

${ }^{5}$ Mochtar Kusumaatmadja, Hukum Laut Internasional Cetakan ke-3,(Binacipta 1986).[128]. 
hukum laut pertama di Jenewa tahun 1958. Konvensi ini pun memuat berbagai prinsip pokok yang terdiri dari: 6

1) Mengatur rezim-rezim wilayah laut;

2) Mengakui kedaulatan,hak berdaulat, dan yurisdiksi negara pantai di laut;

3) Mengakui rezim hukum negara kepulauan;

4) Mengatur hak dan kewajiban kapal di laut bebas;

5) Mencegah adanya benturan kepentingan antara negara pantai dan negara bendera kapal dan menyediakan semua penyelesaian konflik.

Sejarah pembentukan zona tambahan dibentuk dari hukum kebiasaan internasional yang sudah dikenal sejak perang dunia II dan diperkenalkan oleh Onde de Bouen dalam konferensi Internasional tentang Perikanan yang diselenggarakan di Madrid, Spanyol. ${ }^{7}$ Onde de Bouen memperkenalkan cikal bakal konsep zona tambahan sendiri dapat ditelusuri mulai dari penerapan "Hovering Acts" oleh Inggris di abad ke-18. Peraturan perundangan tersebut mengatur bahwa Inggris dapat menerapkan yurisdiksinya atas hal-hal yang terkait masalah kepabeanan (custom matters) hingga 300 leagues (900 mil laut) diukur dari pinggir pantai dan dapat pula melakukan penangkapan terhadap penyelundupan yang terjadi dalam zona tersebut. Konsep zona tambahan sebagaimana dicetuskan dalam Hovering Acts tersebut kemudian berkembang di abad ke-19 di mana sejumlah negara menerapkan yurisdiksinya melampaui laut territorialnya dengan tujuan melindungi pendapatan terhadap kejahatan penyelundupan dan kesehatan masyarakat terhadap merebaknya penyakit menular.

Pengaturan Zona Tambahan sebagai rejim khusus dalam hukum internasional muncul pertama kali pada The Hague Conference 1930. Baik dalam preparatory work maupun pada saat konferensi, konsep ini cenderung ditujukan bagi negara untuk melakukan langkah penegakan hukum (enforcement) dari pada sekedar bersifat pengaturan (legislative jurisdiction). ${ }^{8}$ Namun, kegagalan Konferensi Kodifikasi Den

${ }_{6}$ Pertemuan Kelompok Ahli, Implementasi Konvensi PBB Tentang Hukum Laut (UNCLOS 1982): Refleksi Peringatan World Oceans Day, (Badan Pengkajian dan Pengembangan Kebijakan Kementerian Luar Negeri RI 2009).[67].

7 Pusat Perencanaan Pembangunan Hukum Nasional Kementrian Hukum dan HAM, Naskah Akademik Rancangan Undang-Undang tentang Zona Tambahan, (2014).[10]

8 ibid.[13]. 
Haag tahun 1930 menyebabkan konsepsi zona tambahan ini (yang biasanya dikaitkan dengan laut territorial) selanjutnya ditentukan sendiri-sendiri oleh negara-negara bersangkutan menurut kepentingan mereka masing-masing. Keberlangsungan untuk adanya pengaturan zona tambahan, dilanjutkan dengan pembahasan oleh Komite I Konferensi Hukum Laut I yang kemudian menghasilkan Geneva Convention on the Territorial Sea and the Contiguous Zone 1958 hingga lebih diperjelas pada UNCLOS 1982 dalam pasal 33-nya. Pasal 33 UNCLOS 1982 sudah jelas dalam mengartikan yurisdiksi yang diperoleh setelah menerapkan adanya zona tambahan namun di dalam pasal tersebut hanya mengatur berkaitan dengan yurisdiksi khusus, sementara pada pasal 303 ayat (2) memungkinkan negara untuk menerapkan kewenangan hukumnya di bidang perlindungan warisan budaya bawah laut (protection of underwater cultural heritage). Namun kewenangan tersebut sebatas terkait dengan ekplorasi dan pemindahan benda-benda arkeologis dan kesejarahan yang terletak di bawah laut. Hal tersebut pun hanya dapat dilakukan terhadap benda arkeologis dan kesejarahan yang terletak hingga 24 mil laut dihitung dari garis pangkalnya. Konsep yurisdiksi zona tambahan yang disebut sebagai yurisdiksi khusus ini selanjutnya dapat disebut sebagai zona spesial atau yang biasa disebut Zona Transisi antara laut bebas dengan laut territorial suatu negara. Zona ini berfungsi untuk mengurangi kontras antara laut territorial yang rezim hukumnya tunduk seluruhnya pada kedaulatan negara pantai, dengan rezim hukum laut bebas dimana berlaku rezim freedom of the seas. ${ }^{9}$

Dalam melaksanakan kekuasaan pengawasan oleh negara pantai terhadap zona tambahan negaranya sebagaimana pandangan dari Sir Gerald Fitzmaurice ${ }^{10}$ tentang pasal 24 ayat (1) Geneva Convention on the Territorial Sea and the Contiguous Zone 1958, yaitu:

"It is control, not jurisdiction, that is exercised. The power is primarily of the policeman, rather than of the administrator or of the judge. Although the two ensuing sub-heads (a) and (b) of the paragraph envisage punishment as well

\footnotetext{
9 Boer Mauna, Hukum Internasional: Pengertian Peranan dan Fungsi Dalam Era Dinamika Global, (PT Alumni 2008).[377].

${ }^{10}$ Shigeru Oda, The Concept of the Contiguous Zone [1962], < https://www.cambridge.org/ core/journals/international-and-comparative-law-quarterly/article/concept-of-the-contiguous-zone/ $\underline{\text { C4684349D12D68FCC6927929FF6EFD53> }}$, diakses pada tanggal 10 April 2019
} 
as prevention, yet taken as a whole, the power is essentially supervisory and preventative. The basic object is anticipatory. No offence against the law of the coastal state is actually being committed at the time. The intention is to avoid such an offence being committed subsequently when, by entering the territorial sea, the vessel comes within the jurisdiction of the coastal State; or else to punish such an offence already committed when the vessel was within such jurisdiction".

Diartikan, untuk menghindari agar pelanggaran-pelanggaran tidak dilakukan, dan bahwa kekuasaan negara pantai dapat dibedakan, yaitu kekuasaan mencegah hanya dapat dilakukan atas kapal-kapal yang akan masuk dan kekuasaan menghukum diterapkan terhadap kapal-kapal yang akan meninggalkan zona tambahan.

\section{Implementasi Zona Tambahan di Indonesia}

Undang-undang Republik Indonesia Nomor 43 tahun 2008 tentang Wilayah Negara menyebutkan dalam Pasal 1 angka 3, bahwa Wilayah Yurisdiksi Indonesia adalah wilayah di luar wilayah negara yang terdiri atas zona ekonomi eksklusif, landas kontinen, dan zona tambahan dimana negara tersebut memiliki hak-hak berdaulat dan kewenangan tertentu lainnya sebagaimana diatur dalam peraturan perundang-undangan dan hukum internasional. Dalam Undang-undang Wilayah Negara tersebut menyatakan dengan jelas adanya zona tambahan sebagai bagian zona maritim yang diakui secara nasional. Indonesia sendiri telah meratifikasi UNCLOS 1982 sesuai Undang-undang Nomor 17 tahun 1985 tentang Pengesahan UNCLOS 1982 yang juga telah mengatur zona tambahan pada pasal 33. Sehingga dapat diartikan upaya untuk mensinkronkan pengaturan nasional dengan hukum internasional sudah terjadi, namun di dalam penerapannya, hal tersebut tidak sepenuhnya ter-akomodir. Pasal 33 ayat 1 UNCLOS 1982 dengan jelas menerangkan bahwa maksud dari adanya zona tambahan untuk mencegah adanya pelanggaran peraturan berkaita dengan bea cukai, fiskal, imigrasi dan sanitasi di wilayah negara pantai yang bersangkutan. Namun Praktek penerapan dari keempat hal tersebut tidak sepenuhnya ter-realisasikan dengan nyata.

Penyelundupan illegal barang - barang yang masuk keluar di Indonesia, menjadi salah satu contoh permasalahan di bidang bea cukai. Sedikitnya 53 kasus penyelundupan barang-barang illegal telah terjadi sepanjang tahun 2018 di Batam, 
Kepulauan Riau. Barang-barang illegal yang masuk dalam penyelundupan terbanyak, yakni berjenis minuman keras, rokok, narkotika, dan barang-barang eks-Batam lainnya dengan perkiraan total kerugian yang ditaksir bernilai Rp. 4 Triliun rupiah. ${ }^{11}$ Hal tersebut dapat terjadi dikarenakan kondisi perijinan barang yang masuk maupun keluar masih dilakukan pada pelabuhan dan setelah keluar dari pelabuhan, proses pemeriksaan pun telah selesai. Namun apabila zona tambahan dapat diterapkan, proses penjagaan tidak hanya sebatas di daratan namun aparat penegak hukum yang memiliki landasan hukum kuat juga memiliki kewenangan untuk menindak di wilayah zona tambahan sebagaimana pasal 33 ayat (2) UNCLOS 1982.

Dalam bidang keimigrasian, Indonesia merupakan tempat favorit bagi imigran illegal untuk bertempat tinggal atau hanya sebagai tempat transite untuk mencari suaka yang lebih baik. ${ }^{12}$ Alasan utama bagi para imigran illegal untuk masuk ke dalam Indonesia sebagaimana data yang ditampilan sebagai berikut:

Gambar 1. Alasan Masuk ke Indonesia Secara Ilegal

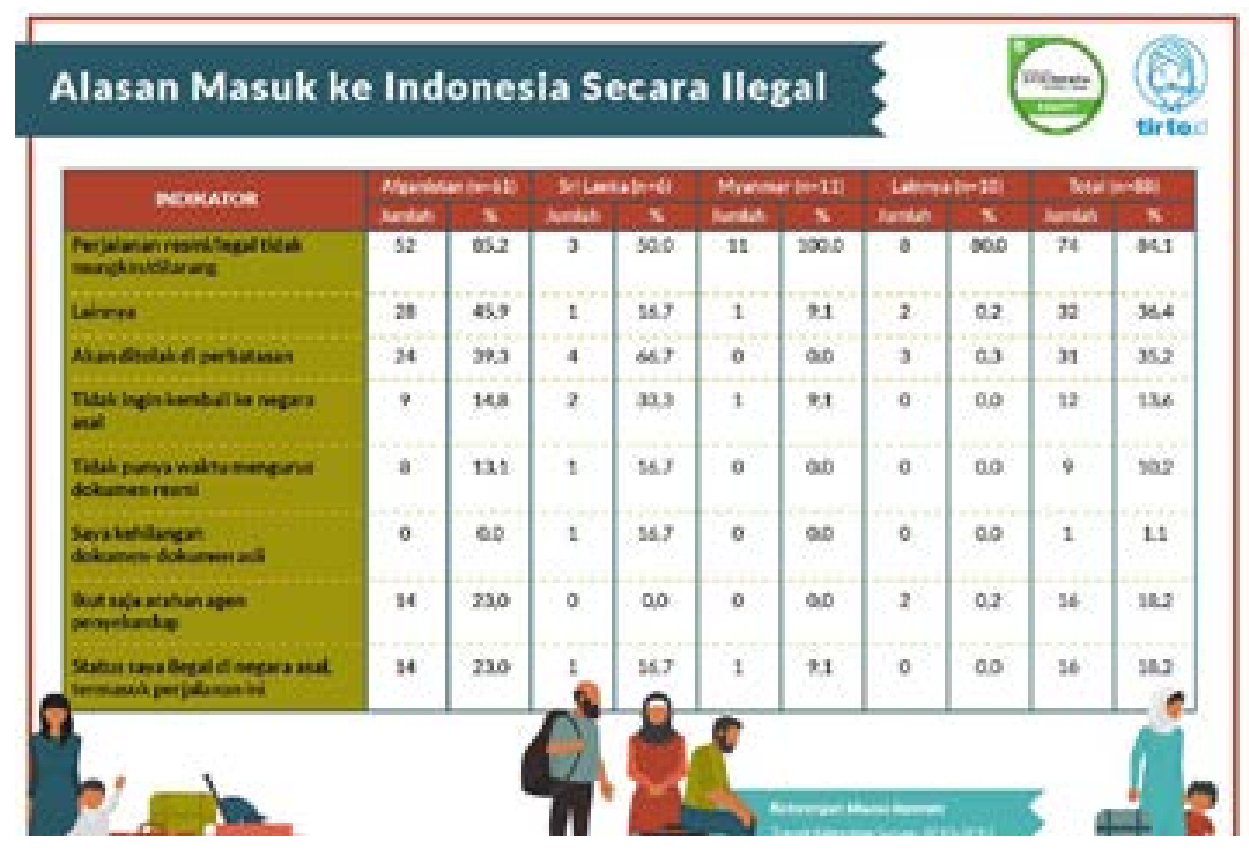

Sumber 1. tirto.id

11 Wildan Catra Mulia, 'Bongkar 53 Kasus di 2018, Barang Illegal Senilai Rp 4 Triliun Diamankan',(Selasa 15 Januari 2019),<https://www.inews.id/news/nasional/bongkar-53-kasus-di2018-barang-ilegal-senilai-rp4-triliun-diamankan/430981>, diakses 10 April 2019.

12 Irma Ganesia, 'Indonesia Negara Transit Favorit Imigran Gelap',(20 September 2018), $<$ https://tirto.id/indonesia-negara-transit-favorit-imigran-gelap-cZ7w $>$, diakses pada tanggal 8 april 2019 
Per 31 Januari 2017 jumlah imigran illegal menurut UNHCR adalah 14.425 orang. ${ }^{13}$ Jumlah imigran illegal yang masuk ke Indonesia dengan angka yang besar didasarkan pada lemahnya pencegahan masuknya imigran illegal. Selain dari masalah keimigrasian, masalah fiskal dan sanitasi juga perlu untuk dikaji ulang agar zona tambahan dapat berperan penting dalam menjaga wilayah laut.

Berkaitan dengan kondisi praktik pelanggaran hukum di Zona Tambahan di Indonesia, tidak terlepas dari bagaimana regulasi nasional di tiap bidang yang dimaksud dalam pengaturan zona tambahan,yaitu:

Kepabeanan, Undang-undang Nomor 17 tahun 2016 tentang perubahan atas undang-undang Nomor 10 tahun 1995 tentang Kepabeanan (yang selanjutnya disebut undang-undang Kepabeanan) pada Pasal 1 angka 1 mengartikan kepabeanan adalah segala sesuatu yang berhubungan dengan pengawasan atas lalu lintas barang yang masuk atau keluar daerah pabean serta pemungutan bea masuk dan keluar, kemudian dalam Pasal 1 angka 2 menyebutkan bahwa yang dimaksud Daerah Pabean adalah Wilayah Republik Indonesia yang meliputi wilayah darat, perairan dan ruang udara di atasnya, serta tempat-tempat tertentu di Zona Ekonomi Eksklusif dan landas kontinen yang didalamnya berlaku undang-undang ini. Tetapi pengaturan tentang daerah kepabeanan tidak memuat zona tambahan sesuai yang ditentukan dalam UNCLOS 1982, dan mengatur mengenai zona maritim lainnya. Dalam pasal tersebut menyebutkan tempat-tempat tertentu yang dimaksud sesuai pembagian zona maritim ialah Zona Ekonomi Eksklusif (ZEE) dan landas kontinen, kemudian yang perlu dipahami lebih lanjut konsep dan teknis dari zona tambahan yang sejatinya memastikan bahwa kepabeanan hanya dapat ditegakkan pengaturannya sebatas sampai zona tambahan. Undang-undang kepabeanan justru menetapkan ZEE dan landas kontinen kedalam pengertian tentang daerah pabean. Dalam hal ini, Pasal 56 UNCLOS 1982 menyebutkan terkait hak dan kewajiban negara pantai dalam Zona Ekonomi Eksklusif yakni memiliki kedaulatan sebatas

\footnotetext{
${ }^{13}$ Galang Aji Putro, 'Imigran Ilegal Penuhi Indonesia Ini Langkah Pemerintah',(09 Maret 2017), $<$ https://news.detik.com/berita/d-3442963/14425-imigran-ilegal-penuhi-indonesia-inilangkah-pemerintah $>$, diakses pada tanggal 9 April 2019
} 
eksplorasi dan eksploitasi sumber daya alam baik hayati maupun non-hayati serta keperluan lain-lain yang masih memiliki relevansi yaitu risalah ilimiah kelautan ${ }^{14}$ dan Pasal 77 UNCLOS 1982 tentang hak negara pantai atas landas kontinen juga menjelaskan yang dimaksud hak tersebut ialah sebatas eksploitasi dan eksplorasi sumber kekayaan alam yang terkandung didalam landas kontinen tiap negara. Selain hak dan kewajiban yang berbeda, lebar laut yang dimaksud jelas tidak sepadan antara zona tambahan dengan zona ekonomi eksklusif dan landas kontinen, baik dalam Pasal 57 tentang lebar zona ekonomi eksklusif dan Pasal 76 tentang batasan landas kontinen menyatakan batasan lebaran tidak boleh melebihi 200 mil laut dari garis pangkal.

Fiskal, Menurut Kamus Besar Bahasa Indonesia (KBBI), fiskal ialah yang berkenaan dengan urusan pajak atau pendapatan negara. Pengaturan mengenai fiskal dapat ditemukan dalam Undang-undang Nomor 17 tahun 2003 tentang Keuangan Negara yang selanjutnya disebut Undang-undang Keuangan Negara, Pasal 6 Undang-undang keuangan negara, pada ayat (2) menyatakan bahwa kekuasaan untuk pengelolaan fiskal diberikan oleh presiden kepada menteri keuangan dan dalam Pasal 8 menjelaskan dalam rangka pelaksanaan pengelolaan kekuasaan atas pengelolaan fiskal, menteri keuangan mempunyai tugas sebagai berikut:

a. Menyusun kebijakan fiskal dan kerangka ekonomi makro;

b. Menyusun rancangan apbn dan rancangan perubahan apbn;

c. Mengesahkan dokumen pelaksanaan anggaran;

d. Melakukan perjanjian internasional di bidang keuangan;

e. Melaksanakan pemungutan pendapatan negara yang telah ditetapkan Dengan undang-undang;

f. Melaksanakan fungsi bendahara umum negara;

g. Menyusun laporan keuangan yang merupakan pertanggungjawaban Pelaksanaan apbn;

h. Melaksanakan tugas-tugas lain di bidang pengelolaan fiskal berdasarkan ketentuan undang-undang."

Dari kedelapan fungsi tersebut tidak ada yang mengatur mengenai persoalan pelanggaran peraturan fiskal, sebagaimana yang kita ketahui, zona tambahan dalam 
Pasal 33 ayat (1) UNCLOS 1982 menyebutkan adanya zona tambahan untuk mencegah pelanggaran peraturan fiskal.

Keimigrasian, Ketentuan umum dalam pasal 1 Undang-undang Nomor 6 tahun 2011 tentang keimigrasian (yang selanjutnya disebut undang-undang keimigrasian) menyebutkan dalam Pasal 1 angka 1, keimigrasian adalah hal ihwal lalu lintas orang yang masuk atau keluar wilayah Indonesia serta pengawasannya dalam rangka menjaga tegaknya kedaulatan negara. Selanjutnya pada Pasal 1 angka 2 yang dimaksud dengan wilayah Indonesia adalah seluruh wilayah Indonesia serta zona tertentu yang ditetapkan berdasarkan undang-undang. Untuk mengetahui lebih lanjut maksud zona tertentu yang ditetapkan berdasarkan undang-undang, di dalam penjelasan atas undang-undang keimigrasian pada Pasal 1 termaktub "sudah jelas". Diartikan lebih lanjut undang-undang keimigrasian juga belum mengatur adanya zona tambahan, dimana hal tersebut tidak sesuai dengan upaya undangundang nomor 17 tahun 1985 tentang pengesahan UNCLOS 1982 oleh Indonesia untuk melakukan ratifikasi secara utuh terhadap UNCLOS 1982.

Sanitasi, Menurut Kamus Besar Bahasa Indonesia, sanitasi adalah usaha untuk membina dan menciptakan suatu keadaan yang baik di bidang kesehatan. Peraturan tentang kesehatan telah diatur dalam Undang-undang nomor 36 tahun 2009 tentang Kesehatan (yang selanjutnya disebut undang-undang kesehatan). Dalam undang-undang ini, pengaturan terkait pencegahan dan penindakan akan adanya pelanggaran dibidang kesehatan hanya mengatur terkait ketentuan pidana yang tidak memasukkan sama sekali adanya unsur zona tambahan. Selain dari undang-undang Kesehatan, pengaturan mengenai sanitasi juga terdapat dalam Undang-undang nomor 6 tahun 2018 tentang Kekarantinaan Kesehatan (yang selanjutnya disebut undang-undang Kekarantinaan Kesehatan). Pengertian kekarantinaan kesehatan menurut Pasal 1 angka 1 adalah upaya mencegah dan menangkal keluar masuknya penyakit yang dapat menjadi risiko bagi kesehatan masyarakat sehingga dapat menimbulkan kedaruratan kesehatan masyarakat. Yang dimaksud dalam kedaruratan kesehatan, pada intinya menurut angka 2 dalam pasal ini adanya kejadian kesehatan masyarakat luar biasa dengan ditandai penyebaran 
penyakit menular sehingga menimbulkan bahaya kesehatan terhadap masyarakat umum dan berpotensi menyebar lintas wilayah atau lintas negara. Kondisi kedaruratan kesehatan ini lah yang menjadi alasan untuk diperlukannya sebuah karantina dengan penjagaan melalui "pintu masuk". Pintu masuk yang dimaksud merupakan gerbang keluar masuknya baik manusia, barang mapun alat angkut berkaitan dengan masalah kekarantinaan kesehatan yang terletak di pelabuhan, Bandar udara mapun pos lintas batas darat negara. Seperti peraturan-peraturan sebelumya yang jelas tidak memuat zona tambahan sebagai suatu zona maritim laut yang berfungsi dalam pencegahan dan penindakan permasalahan sanitasi di Indonesia namun justru tidak dimuat dalam peraturan terbaru ini. Memperhatikan pula kondisi zona tambahan yang terletak di lautan dan jauhnya 24 mil laut dari garis pangkal, dapat meminimalisir pula kondisi kedaruratan kesehatan masyarakat yang terjadi di daratan karena penjelasan mengenai pintu masuk sesuai Pasal 1 angka 3 tersebut.

Kemudian disesuaikan dengan praktik penerapan pengaturan zona tambahan di negara lain, yakni:

Amerika Serikat, dimana sampai sekarang Amerika Serikat masih belum meratifikasi UNCLOS 1982, dalam sejarah perumusan konvensi hukum laut internasional tersebut Amerika Serikat merasa tidak diuntungkan, terutama mengenai kawasan dasar laut Internasional. Namun, pada dasarnya Amerika Serikat masih menerima berkaitan dengan prinsip-prinsip yang diatur dalam UNCLOS 1982. Pada tanggal 2 September 1999, Presiden Amerika Serikat, William J. Clinton menyatakan bahwa Amerika Serikat juga memiliki zona tambahan. Dari pernyataan tersebut lebar zona tambahan Amerika Serikat sebagaimana yang diatur oleh hukum laut Internasional yaitu sampai 24 mil laut dari garis pangkal. Seperti pembagian zona maritime menurut UNCLOS 1982, zona tambahan Amerika Serikat merupakan kelanjutan dari laut territorial Amerika Serikat, sehingga Amerika Serikat juga memiliki yurisdiksi untuk melakukan pengawasan dan pencegahan terhadap pelanggaran-pelanggaran atas pengaturan di bidang bea cukai, fiskal, keimigrasian, dan sanitasi. Selain keempat hal yang telah diatur dalam Pasal 33 
ayat (1) UNCLOS 1982 tentang Zona Tambahan, Amerika Serikat juga mengatur akan kepentingan pengambilan benda berharga yang ada di wilayah laut sampai 24 mil laut tersebut.

Australia, Pengaturan Australia tentang zona tambahan sebagaimana diatur dalam Sea and Submerged Land Act 1973, dimana pembagaian zona maritime menurut Australia antara lain:

a. Coastel Water, berjarak 3 mil laut dari garis pangkal pantai. Dimana zona maritime ini merupakan yurisdiksi yang dimilki oleh negara bagian

b. Laut territorial, berjarak 12 mil laut dari garis pangkal pantai. Dalam zona maritime ini Australia mempunyai kedaulatan dan memberikan hak lintas damai bagi kapal asing

c. Zona Tambahan, berjarak 24 mil laut dari garis pangkal pantai. Dalam zona maritime ini Australia memiliki yurisdiksi di bidang custom, fiscal, immigration dan sanitary laws.

d. Zona Ekonomi Eksklusif, berjarak 200 mil laut dari garis pangkal pantai. Dalam zona maritime ini Australian memiliki hak berdaulat atas sumber daya alam.

Berkaitan dengan zona-zona maritime sebagaimana yang telah disebutkan di atas, Australia mempunyai strategi dalam melindungi wilayah-wilayah laut tersebut yang disebut Border Protection Command. ${ }^{15}$ Tujuan dari strategi ini untuk melindungi sumber daya alam dalam pembangunan berkelanjutan serta dapat mengkoordinasikan terkait pencegahan, pengawasan dan penindakan terhadap ancaman-ancaman di wilayah laut.

Kedaulatan Indonesia adalah kewenangan penuh atas wilayah territorial baik dari wilayah darat maupun laut Indonesia memiliki hak-hak berdaulat dengan melakukan pemanfaatan dan pengelolaan atas hal-hal tertentu di zona maritim yang telah ditetapkan oleh hukum Internasional UNCLOS 1982. ${ }^{16}$ Salah satu zona yang belum diatur secara khusus di Indonesia dalah Zona Tambahan. Zona tambahan mempunyai yurisdiksi khusus yang dapat melakukan pengelolaan dan pemanfaatan serta dapat melaksanakan fungsi pengawasan dan penindakan pelanggaran

\footnotetext{
${ }^{15}$ Departemen Pertahanan Australia, <http://www.defence.gov.au/Operations/BorderProtection/default.asp > , diakses 10 April 2019.

${ }^{16}$ Bambang Wahyudi, 'Urgensi Penetapan Rezim Hukum Zona Tambahan dalam Menanggulangi Kejahatan Penyelundupan Manusia’, <http://hukum.studentjournal.ub.ac.id/index.php/hu$\underline{\mathrm{kum} / \text { article/view/1283/1216 }}$ >.[7].
} 
berkaitan dengan bidang bea cukai, fiskal, imigrasi dan sanitasi. Berkaitan dengan hak berdaulat yang dimilki Indonesia, adanya hak pengejaran seketika (hot pursuit) yang terbatas penerapannya apabila zona tambahan masih belum ditetapkan di Indonesia. Hasyim Djalal, pakar hukum laut Indonesia menyatakan bahwa belum ada satupun batas yang ditetapkan dengan negara tetangga yang berkaitan dengan zona tambahan. Selain itu, Indonesia belum mengundangkan zona tambahan dimana negara-negara tetangga lain seperti Malaysia, Philipina, Thailand dan Australia yang sudah meng-undangkannya, hal ini kemudian menjadi urgensi lainnya untuk segera dirundingkan dengan negara-negara tetangga tersebut dengan melakukan perjanjian berkaitan dengan batasan-batasan antar negara terhadap masing-masing zona tambahan. ${ }^{17}$

Pentingnya penetapan zona tambahan di Indonesia karena banyaknya permasalahan baik dari bidang bea cukai, fiskal, imigrasi dan sanitasi yang perlu untuk segera ditanggulangi dengan peraturan hukum yang jelas dan konkret. Dari berbagai peraturan perundang-undangan yang ada, masih banyaknya perundangundangan nasional yang belum sepenuhnya mengakomodir akan adanya normanorma mengenai Zona Tambahan sehingga yang menjadi urgensi adalah perlunya zona tambahan dibuatkan undang-undang tersendiri agar menjadi sebuah kejelasan akan pengaturan zona tambahan di Indonesia. Kemudian, perlunya penyempurnaan peraturan perundang-undangan dengan aturan khusus yang berkaitan dengan fungsi-fungsi dari zona tambahan, yaitu peraturan perundang-undangan mengenai bidang bea cukai, fiskal, keimigrasian dan juga sanitasi.

\section{Kesimpulan}

Zona Tambahan sebagaimana fungsinya yakni mencegah dan menghukum adanya pelanggaran peraturan perundang-undangan tentang bea cukai, fiskal, imigrasi atau saniter di wilayah yang jaraknya 24 mil laut dari garis pangkal pantai. Secara konsep, Zona Tambahan adalah bagian dari yurisdiksi negara dikarenakan

\footnotetext{
${ }^{17}$ Hasyim Djalal, 'Mengelola Potensi Laut Indonesia', (2013) No. 2 Majalah Hukum Nasional.[109-110].
} 
masih adanya kekuasaan sesuai Pasal 33 UNCLOS 1982 sehingga sering disebut sebagai "yurisdiksi khusus". Kemudian urgensi diperlukan penetapan Zona Tambahan, dikarenakan negara-negara pantai memerlukan kekuasaan untuk melakukan pengamanan terhadap kepentingan-kepentingan negara seperi bidangbidang yang telah dijelaskan sebelumnya.

Zona Tambahan telah diakui di Indonesia sebagaimana tertulis dalam Pasal 1 angka 3 Undang-undang Nomor 43 Tahun 2008 tentang Wilayah Negara, yakni wilayah yurisdiksi Indonesia adalah wilayah laut di luar laut territorial yang masih menjadi bagian dalam yurisdiksi Indonesia, dimana salah satunya adalah Zona Tambahan, namun pengaturan tersebut tidak diimplementasikan dengan baik ke dalam masing-masing peraturan perundang-undangan Indonesia baik di bidang bea cukai, fiskal, imigrasi dan saniter.

\section{Daftar Bacaan}

\section{Buku}

Syahmin A.K., Beberapa Perkembangan dan Masalah Hukum Laut Internasional (Sekitar Penegakan Hukum di Perairan Yurisdiksi Nasional Indonesia Dewasa Ini), (Binacipta 1988).

Peter Mahmud Marzuki, Penelitian Hukum, (Prenadamedia Group 2016).

Mochtar Kusumaatmadja, Hukum Laut Internasional, (Binacipta 1986).

Boer Mauna, Hukum Internasional: Pengertian Peranan dan Fungsi Dalam Era Dinamika Global, (PT Alumni 2008).

\section{Makalah}

BPHN Departemen Hukum dan HAM RI disusun oleh Tim Kerja di Bawah Pimpinan Prof. Dr. Etty R. Agoes, S.H., LL.M.,(2008), Laporan Tim Naskah Akademik tentang Zona Tambahan Indonesia: Analisis dan Evaluasi Hukum tentang Zona Tambahan.

Pertemuan Kelompok Ahli, Implementasi Konvensi PBB Tentang Hukum Laut (UNCLOS 1982): Refleksi Peringatan World Oceans Day, (Badan Pengkajian dan Pengembangan Kebijakan Kementerian Luar Negeri RI 2009). 
Pusat Perencanaan Pembangunan Hukum Nasional Kementrian Hukum dan Naskah Akademik Rancangan Undang-Undang tentang Zona Tambahan, (2014).

Hasyim Djalal, Mengelola Potensi Laut Indonesia, (2013), No. 2 Majalah Hukum Nasional.

\section{Laman}

Kementrian Kelautan dan Perikanan Republik Indonesia, (2018) <https://kkp.go.id/ artikel/2233-maritim-indonesia-kemewahan-yang-luar-biasa $>$, diakses pada 6 September 2018.

Shigeru Oda, The Concept of the Contiguous Zone, (1962), <https:// www.cambridge.org/core/journals/international-and-comparativelaw-quarterly/article/concept-of-the-contiguous-zone/ C4684349D12D68FCC6927929FF6EFD53>, diakses pada tanggal 10 April 2019.

Galang Aji Putro, 'Imigran Ilegal Penuhi Indonesia Ini Langkah Pemerintah',(09 Maret 2017), <https://news.detik.com/berita/d-3442963/14425-imigranilegal-penuhi-indonesia-ini-langkah-pemerintah $>$, diakses pada tanggal 9 April 2019.

DepartemenPertahananAustralia, <http://www.defence.gov.au/Operations/ BorderProtection/default.asp $>$, diakses 10 April 2019.

Bambang Wahyudi, 'Urgensi Penetapan Rezim Hukum Zona Tambahan dalam Menanggulangi Kejahatan Penyelundupan Manusia', <http://hukum. studentjournal.ub.ac.id/index.php/hukum/article/view/1283/1216>.

HOW TO CITE: Giustin Aryahya Lubis, 'Implementasi dan Urgensi Pengaturan Zona Tambahan di Wilayah Perairan Indonesia Berdasarkan United Nations Convention On The Law Of The Sea 1982' (2019) Vol. 2 No. 5 Jurist-Diction. 